\title{
O Engasgo de Rosa e a Confirmação Milagrosa
}

Luiz Roncari

Um dia Rosa se deparou com o modernismo

Era uma pedra no meio do caminho

Dificil de deglutir

Os três Andrade

(epígrafe psicografada na mesa branca do centro Casa do Boi Sangrado, em 31 de outubro de 1999)

A novela "São Marcos" tem uma particularidade na obra do "primeiro Guimarães", o dos livros Sagarana, Corpo de Baile e Grande Sertão: Veredas ${ }^{1}$. O que a distingue é o fato do narrador, na primeira pessoa do singular, coincidir com o protagonista; ao lado do autor, são a mesma pessoa, desse modo, portadoras da mesma formação e experiência. A essa coincidência, o próprio herói-narrador faz questão de referir-se, pelo menos por duas vezes, lembrando ser ele mesmo homônimo dos pássaros joão-de-barro e joão-grande. $\mathrm{O}$ que muda de uma figura para outra é o plano onde atuam e o tipo de problemas que enfrentam enquanto herói, narrador ou autor, ou seja, como protagonista das ações, narrador dos fatos e autor da novela. O problema do herói é de ordem ético-religiosa, ele vive as conseqüências das suas ações e opções, no caso, da concordância ou não com as crenças dos homens do Calango-Frito; o problema do narrador é de ordem cultural e de ponto de vista, resulta da escolha de que posição narrar e de como expressar a visão do outro, homens rústicos do campo, distintos dele, um sujeito da cidade e 
culto, diferente tanto no seu modo de conceber a religiosidade como de exprimi-la; e o problema do autor é mais complicado, é de ordem conceitual e estética, envolve questões relativas à sua visão de mundo e escolhas formais, de que relações estabelecer com as tendências culturais e literárias dominantes no seu tempo. Aqui é preciso recordar que o tempo político-institucional no qual a n ovela foi escrita, 1937, é aquele marcado pela revolução de 30 e tudo o que resultou dela, particularmente o que passamos a chamar de "política getulista"; e o tempo literário-cultural está ainda envolvido no debate em torno das questões colocadas pelos vários movimentos modernistas, embora agora numa perspectiva bem mais crítica, em que as opções estéticas envolviam também questões éticas e ideológicas ${ }^{2}$.

São problemas dessas diferentes ordens - a do herói, a do narrador e a do autor - que teremos de enfrentar, procurando ch egar a algumas respostas, a partir principalmente da análise e inte rpretação do texto, mas sem recusarmos qualquer tipo de apoio prestado por informações externas vindas do contexto históricoliterário. Essas questões também não serão discutidas separadamente, mas à medida que forem sendo defrontadas; assim, podemos transitar de uma ordem de problemas à outra sempre que necessário. Partindo do pressuposto de que a novela é parte de uma realidade maior e, ao mesmo tempo, a contém, pois pretende ta $\mathrm{m}$ bém reduzir e condensar no essencial esse todo de que faz parte, respeitando as mediações, tudo pode nos ajudar para melhor decifrála. Parece-me ser esse o termo mais adequado. Embora a leitura de Guimarães Rosa apele para a empatia e a encantação (quantos não se deixaram possuir por ele e saíram imitando-o; o melhor exemplo é o caso da sua filha, Vilma), a atitude do crítico, entretanto, creio dever ser a do desconfiado Ulisses: manter a distância e enfrentar o desafio. Isso porque a astúcia e a estratégia literária do autor são as de criar enigmas e mistérios, escrevendo de modo cifrado e mist u- 
rando aos fatos da experiência uma quantidade de elementos míticos e cabalísticos, o que faz nos imaginarmos mexendo com santos e demônios; porém isso deve ser mais uma razão para reafirmar no leitor avisado o esforço crítico e decifratório, como forma de não sucumbir ao mistério, cujo significado, entretanto, também precisa ser compreendido ${ }^{3}$.

Ao contrário do que acontece em outras novelas e no próprio Grande Sertão, em "São Marcos" o autor não se apresenta lateralmente, como personagem secundário ou interlocutor silencioso. Nessa novela, ele está no centro mesmo dos acontecimentos e estes são vividos, vistos, narrados e interpretados diretamente por ele, tornando muito distintas a elocução culta e sofisticada do narrador e as expressões rústicas e estropiadas da gente do lugar. Ela traz ainda muito diferenciadas a expressão do narrador e a das person agens, e, em algumas passagens, pode se enquadrar ainda naquilo que Antonio Candido chamou de "regionalismo entre aspas", na primeira resenha que escreveu sobre Sagarana, onde ele procurava distinguir o regionalismo de Guimarães do regionalismo mais co nvencional, embora, em outros momentos, a sua escrita já aprese ntasse uma tessitura característica das obras subseqüentes. Talvez, por isso, o crítico tenha considerado que apenas a forma nova de trabalhar o paisagísitico-regional salvasse o seu valor literário. ${ }^{4}$ Entretanto, podemos observar como, apesar do herói-narrador ser formado numa cultura urbana e sofisticada, ele participa da ment alidade supersticiosa e crédula das pessoas da região, ainda que não inteiramente, como procura afirmar logo no parágrafo de abertura: "Naquele tempo eu morava no Calango-Frito e não acreditava em feiticeiros" 5 . Uma das perguntas que a novela nos coloca é se o herói-narrador depois passou a acreditar em feiticeiros, se conve rteu-se à crença na magia ou confirmou-se no seu ceticismo. Nos dois parágrafos seguintes à essa abertura, ele enumera as superstições e crendices dos homens do lugar, acentuando nelas os seus 
aspectos absurdos e jocosos; porém, ao mesmo tempo, afirma os setenta e dois tipos de tabus e regras supersticiosas que ele próprio seguia e respeitava. E conta o caso de Saturnino Pingapinga, que "errou de porta, dormiu com uma mulher que não era a sua, e se curou de um mal de engasgo". Aqui, o autor parodia a história de Cronos, morto engasgado com uma pedra enrolada num cueiro, que ele tentou engolir pensando ser o seu filho, Zeus. Por que o protagonista-narrador, numa aparente contradição, ridiculariza a crendice, de modo a ressaltar a sua distância crítica desse universo, mas, ao mesmo tempo, faz questão de afirmar a sua crença noutras tantas superstições, como o escapulário que carregava consigo, "que garantia a invulnerabilidade a picadas de ofídios"? Porém, ele procura se justificar, dizendo que só acreditava nisso tudo dentro de certos limites, podia aceitar muito daquilo, "Mas, feiticeiros, não".

A função da história, aparentemente, é a de mostrar esse seu engano (ou a sua oscilação e dificuldade de distinção entre a religião e a magia?), pois ela relata uma experiência vivida pelo protag onista, onde parece ficar evidente o poder do feitiço e da reza-brava: o primeiro, que quase o perde, e a segunda, que o salva, portanto, dois instrumentos poderosos. A construção da aparência vai além, na medida em que o autor não tem em vista simplesmente a comprovação dos poderes mágicos de ambos. Sendo a novela narrada por um homem culto, que tem como assunto a sua própria experiência $^{6}$, ele pode criar certas associações, como as que faz entre dois universos distintos do pensamento mítico-mágico-religioso: o si ncrético brasileiro, onde se misturam crenças de origem afro, indíg ena e popular ibérica, com um sincrético universal, composto das mais diversas fontes: gregas, romanas, hebraicas, assírio-caldaicas, egípcias, vedas etc. Essas associações, que podem ser percebidas em toda obra de Guimarães, aqui têm uma particularidade: as suas matrizes estão separadas e pertencem a sujeitos distintos, elas têm 
expressões diferentes e as suturas da soldagem de uma com a outra estão mais visiveis. A referência culta e universal faz parte da formação do herói-narrador-autor, e a popular-regional aparece como algo estranho, do outro, da gente do lugar. O que caracteriza o herói na história é o fato de ele ser um homem culto e de fora, distinto nisso dos habitantes do Calango-Frito, embora o autor também participasse da mentalidade do lugar, pois havia nascido e se criado numa cidadezinha só diferente de lá pelas raízes eruditas, latina e germânica, do seu nome: Cordisburgo.

Essa duplicidade do autor-narrador permite que ele reúna em si as matérias das duas fontes, a erudita e a popular, distintas e contrastantes, porém não opostas. A experiência local do herói lhe permitirá verificar o que tem e o que não tem correspondência com o seu sistema religioso de fonte culta, podendo com isso o sistema religioso popular contribuir para a ampliação da sua visão e a co nfirmação das suas convicções, que, desse modo, podem também aclimatar-se ao lugar. Através dele fica possível uma ida e vinda entre os dois sistemas sincréticos. Assim, muitas das percepções finas vividas com a leitura das fontes míticas e religiosas da literat ura universal podem ser associadas com as manifestações observadas e vividas no mundo rústico e arcaico do interior de Minas. Aos olhos do autor-narrador, uma coisa pode se transformar na outra: o rústico e o arcaico do sertão, juntamente com a variedade da nat ureza, fauna e flora ricas e exuberantes, podem ser narrados numa forma culta; e os elementos e topos das narrativas universais podem ser revividas no meio rústico, ganhando novas roupagens e expressões ${ }^{7}$. Nas outras novelas de Guimarães e no Grande Sertão isso também ocorre, mas de modo mais velado, como uma outra camada de significação sutilmente infiltrada e disseminada pelo autor nas palavras e expressões dos narradores. Esse processo está presente aqui também e é central para a compreensão da novela. Só que em São Marcos o autor-narrador-herói deixa mais explícitos os 
artifícios do seu trabalho, como se tivesse mais dificuldade de apagar as pegadas do seu método de composição. Mas não está só ni sso a importância do seu estudo, o fato de estarem o pensamento literário do autor e a sua estratégia narrativa ainda em gestação, e, por isso, serem revelados mais diretamente. Está também em como foi concebida e trabalhada a relação entre a alta e a baixa cultura (ou a cultura popular), isso tanto como uma questão do autor, a ser resolvida no plano das convicções pessoais, como também um problema da literatura, na época da escrita da novela, e que tinha sido valorizada teórica e praticamente pelos modernistas brasileiros. A questão versa sobre a possibilidade e a validade dos contatos e trocas culturais, principalmente com as manifestações populares, não cultas, e como fazê-lo. Até que ponto era legítimo a alta liter atura valorizar e absorver, enquanto temas e formas, tudo aquilo da cultura popular, como as várias tendências do modernismo tinham tentado fazer, principalmente com os elementos da arte negra e indígena, expressivas de um tipo particular de subjetividade e religiosidade? Este é o problema conceitual e literário enfrentado pelo autor, o caroço do engasgo de Guimarães, para o que não havia ainda encontrado uma solução satisfatória. Sabia que caminho s eguir, mas não estava livre de equívocos e enganos. Daí a necessid ade também de se discutir os pressupostos religiosos e políticos (ideológicos, num sentido amplo) do autor.

São Marcos é a história de uma possessão, de um homem urbano que provoca e desafia os poderes mágicos dos feiticeiros e das rezas dos homens do Calango-Frito, onde ele se situa como um estranho no lugar. É também a história de uma confirmação, o crisma de um nome e de uma visão que foram testadas pelas forças da natureza e da cultura local. Ela relata as ameaças e os riscos vividos por um homem, não de pouca fé, como pode parecer, mas de outra fé religiosa, enquanto herói, e literária, enquanto autor, porque se trata também de um acerto de contas com certas propo- 
sições colocadas pelo modernismo à literatura. É isto que parece estar incubado na caixa preta deste conto, simbolizada pelo João Mangolô, e que não foi aberta ainda pela crítica. $\mathrm{O}$ desafio é abri-la sem cair no mesmo engano em que caíram os que abriram a caixa de Pandora, que se iludiram com o presente ornado por Afrodite. Devemos saber que poderemos encontrar aí encantos e desenca ntos.

E por fim, o tom jocoso com que ele descreve, no início da novela, as crendices dos homens do lugar, talvez signifique que se trata também da história de uma provação e ampliação de visão, de um João que experimenta a situação de José, "nesta história, eu também me chamarei José", que, como o José popular do Drummond, pergunta, "E agora?". Como acomodar essa nova experiência sem apelar para o velho compromisso, nem tragédia nem comédia? Por isso ela tem também as cores fortes do Brasil.

Numa manhã de Domingo, como fazia sempre, o narradorprotagonista dirige-se a um bosque como se fosse para a caça; na verdade, ele ia "contemplar" a natureza, quase no sentido da co ntemplação místicas daquele capaz de ver com os olhos da alma as emanações da mesma fonte a que ela aspira voltar, a vida da natureza como obra da criação, manifestação da sua riqueza e beleza ${ }^{8}$ :

“...eu nào podia deixar o povo saber que eu entrava no mato, e lá passava o dia inteiro, só para ver uma mudinha de cambuí a medrar da terra de-dentro de um buraco no tronco de um camboatã; para assistir à carga frontal das formigas-cabaças contra a pelugem farpada e eletrificada de uma tatarana lançachamas; para namorar o namoro dos guaxes, pousados no ramo comprido da aroeira; para saber ao certo se o meu xará joão-de- 
barro fecharia mesmo sua olaria, guardando o descanso domingueiro; para apostar sozinho, no concurso de salto-à-vara entre os gafanhotos verdes e os gafanhôes cinzentos; para estudar o treino de concentração do jaburu acromegálico; e para rir-me, à glória das aranhas-d'água, que vão corre-correndo, pernilongando sobre a casca de água do poço, pensando que aquilo é mesmo chão para se andar em cima".

No caminho, ele provoca um preto velho, João Mangolô, um feiticeiro que aceita de início as suas brincadeiras, mas que se irrita quando ele mexe com a raça, recitando uns mandamentos que falavam que todo negro era cachaceiro, vagabundo e feiticeiro ${ }^{9}$. $\mathrm{O}$ homem culto, aqui, se faz o portador escarninho da expressão preconceituosa da velha sociedade escravista, mas é enganoso pensar que a oposição no caso é entre uma mentalidade religiosa branca, cristã, e uma negra, afro. O modo como é descrito João Mangolô, a sua cafua e as suas práticas religiosas, caracterizam-no mais como um catimbozeiro, o que o aproxima mais dos caboclos da tradição indígena e da feitiçaria européia medieval do que dos cultos afros organizados, como o candomblé e a macumba. A apresentação que Câmara Cascudo faz desse tipo, no seu livro, Meleagro, é bastante significativa. Melêagros é a figura mitológica que derrotou o javali de Ártemis, o animal selvagem da deusa selvagem, e decepou-lhe a cabeça, dando uma demonstração de força que acabou por perdêlo. É com a cabeça do javali numa das mãos que o herói mítico é representado, um pouco como a cafua do Mangolô, que tem ao lado o chiqueiro onde os porcos chafurdam e se empanturram. É assim que o folclorista descreve o catimbozeiro:

“O 'Mestre' do Catimbó é uma constante etnográfica de surpreendente poderio psicológico. Mantém seu ambiente, 
bailado cotucando os nervos, negras balançando na cadência entorpecedora dos atabaques. O catimbó vai vivendo, apesar de tudo, com a segurança de uma predileçào popular irresistível.

“Nome, organizaçào, funcionamento, tudo está escuro, misturado, confuso. É uma soma de influência e convergência, como todos os cultos. A feição mais decisiva é da feitiçaria européia, o 'mestre' e seu prestígio, a consulta sem obrigação de adesão. Ausência de iniciação, reuniòes festivas, aprendizado ostensivo e sistemático. Os brasis deram sua flora, tuxaúas cheios de mistérios, ensinando remédios ou indo flechar os inimigos, com flechas invisíveis que matam. O negro trouxe a parte mais triste e dolorosa. Seus 'mestres' foram todos catimbozeiros mortos, ex-escravos, vidas sem história, tornados soberanos nos reinos do Vajucá e do Juremal. Viveram, como a maioria dos colegas vive ainda, nas casinhas de palha, de taipa oscilante, fugindo, tremendo das visitas policiais, arrastados como bichos curiosos diante das máquinas fotográficas para a identificação criminal e jamais atendendo curiosidade elegante e jornalística".

Um pouco mais adiante, ele completa o quadro dessa figura que, na literatura brasileira, radica-se na casa do caboclo, onde o Leonardo Pataca, do Memórias de um Sargento de Milicias, foi tomar forte:

“O catimbó é bruxaria sem recorrer ao diabolismo medieval. É a parte não oficial, não ritualística das religiôes negras, americanas e européias. Está condenado pelos concílios da Igreja Católica, pelas instruções de todas as Polícias. Também um pai de terreiro que se preze não dá a um 'mestre' de Catimbó o tratamento de colega nem mesmo a simples tolerância de quem exerce atividade paralela, a distância entre um chauffeur de 
caminhào e um piloto de Constelation. Uma Màe-de-Santo não verá uma catimbozeira com olhos mansos de quem a sabe fiel aos encantos de Iemanjá ou Oxóssi. Uns e outras enxergarào o intruso, o adventício, hostil, desconfiado, zombeteiro, um culto irregular e maldito, sem ligaçào e coerência, sem hierarquia e gradaçòes, vivendo pela exploração do Medo, origem dos deuses pretorianos.

“O Catimbó é o melhor, é o mais nítido dos exemplos desses processos de convergência afro-branca-ameríndia. As três águas descem para a vertente comum, reconhecíveis mas inseparáveis em sua corrida para o Mar"."11

Para a compreensão da história, é importante observar os seguintes aspectos das práticas de João Mangolô: não são essencialmente negras ou afro, mas comuns a outras tradições, européia e indígena; não pertencem a seitas ou religiões organizadas, com rit uais e cultos facilmente identificáveis; seu aspecto é essencialmente pobre e marginal, a que se recorre para resolver problemas práticos da vida ou para a vingança e o mal do outro; e, principalmente, elas estruturam-se a partir de crenças animistas e não naturistas, como as distingue Durkheim ${ }^{11}$ - seria necessário, aqui, todo um trabalho de particularização, mas que fugiria ao nosso propósito, que é de est udo literário. $\mathrm{O}$ que mais interessa para a nossa história, é o fato de ssas práticas invocarem as forças extraordinárias que atuam na terra, através da magia, das simpatias e dos envultamentos, apelando para os espíritos e demônios, em oposição às crenças naturistas, que, segundo Durkheim, evoluíram para as religiões organizadas, que olham para cima e para o celeste, cultuam o divino na terra, e co ntemplam a natureza como obra sua e fonte de constante regener ação.

Depois do herói provocar o João Mangolô, ele continua o seu caminho e logo se encontra com um homem com uma foice, 
que se chama Aurísio Manquitola, "um mameluco brancarano, cambota, anoso, asmático como um fole velho, e com supersenso de cor e casta" (os grifos são meus). É uma outra representação de Cronos/Saturno ${ }^{12}$, só que agora mais efetiva e atuante, como o deus coxo do tempo, o velho com a ceifadeira implacável nas mãos, e que conta para ele uma série de casos sobre o poder da reza-brava de São Marcos. O protagonista conhece a reza e brinca com ela, desafiando os seus poderes, da mesma forma como fizera com os poderes do feiticeiro João Mangolô. Os casos contados pelo Aur ísio-Tempo versam sobre os poderes e os perigos de se brincar com a reza ${ }^{13}$. Como a figura do feiticeiro, a reza-brava não era uma prática religiosa característica, branca, indígena ou negra. Assim como o João Mangalô não pode ser tomado como uma expressão simb ólica só negra, também o Aurísio, "mameluco brancarano", "com supersenso de cor e casta", não pode ser identificado como expre ssão de uma crença só branca, ambos são misturados. Chegando numa bifurcação, o narrador-protagonista toma o carreador da direita, onde se encontrara com o Aurísio; quando se separam, este pega o outro caminho, se entendendo que era o da esquerda: "Bem seu moço, se o senhor vai torar dessa banda de lá, nós temos de se desapartar, que o meu rumo é este aqui". De certo modo, a pass agem simboliza que o caminho da direita é o da contemplação, para onde se encaminha o protagonista, e o da esquerda é o do senhor do tempo ${ }^{14}$.

Ao longo da estrada, o narrador-protagonista tem os olhos voltados para cada manifestação da natureza, da flora e da fauna, das mais exuberantes às mais insignificantes, como os capins, as ervas daninhas e os insetos, mas todos tendo para ele a sua beleza e importância, como se formassem uma única composição. De passagem, ele não deixa de reparar como a estrada dava uma longa volta, só para passar diante da casa de um coronel: "a estradamestra, que enquanto isto tudo, contornou o saco-de-serra, esba n- 
jando chão numa volta quilometrosa, somente para aproveitar a ponte grande e para passar no pé da porta da casa da fazenda do Seu Coronel Modestino Siqueira". A observação parece dizer que, assim como a estrada foi desviada só para beneficiar o Coronel, a sua narrativa também poderia fazê-lo para criticar os desmandos deste mundo, mas com isso ela poderia perder-se, desviando-se do seu verdadeiro fim. Contudo ela faz um longo desvio, para contar um episódio, mas que só aparentemente diverte o leitor do seu fim, pois ela condensa aí o verdadeiro tema da história. O herói passara por um bambual, que lembrou-o de uma correspondência que havia trocado ali, na forma de um desafio, com um "poeta" desconhecido, em que um respondia ao outro, escrevendo nos gomos do bambu gigante. $\mathrm{O}$ estilo usado para relatar essa passagem exibe o gosto dos exotismos e preciosismos da literatura parnasianosimbolista, que procurava a expressão diferenciadora, orientada para a escolha dos termos requintados, nobres e sonoros:

“Os bambús! Belos, como um mar suspenso, ondulado e parado. Lindos até nas folhas lanceoladas, nas espiguetas peludas, nas oblongas glumas... Muito poéticos e muito asiáticos, rumorejantes aos vôos do vento.

"Bem perto que está o bosquete, e eu me entorto de curiosidade; mas vai ser a última etapa: apenas na hora de ir-me embora é que passarei para ver os meus bambús. Meus? Nossos... Porque eles são a base de uma sub-estória, ainda incompleta".

A "sub-estória" ou o desafio nada mais é que a discussão do tema essencial da história que está sendo contada (pelo menos para o autor, podendo não o ser para o leitor de hoje). Ele discorre s obre a escolha que um dia o homem deve fazer entre o céu e a terra, entre o eterno e a "pândega", segundo o termo do herói-narrador. 
Só que essa escolha não era simples, não implicava apenas na exclusão de um ou de outra, mas se apresentava como uma pergunta sobre o modo das suas relações, de como contemplar céu e terra como uma unidade: tornando terrenos os fenômenos celestes ou enxergando o divino nas manifestações terrenas? Esta última era a única escolha possível para um espírito sério, que via a sujeição ao tempo e à morte como uma condenação, estando portanto a saída na busca da superação, sempre sujeita às artimanhas do destino.

A primeira quadrinha encontrada pelo narrador, gravada nos bambus, introduzia justamente essa questão, a da unidade, da relação entre o singular e o plural, do uno e do múltiplo, embora esteja aí disfarçada, como erros gramaticais de quem não dominava a língua e a escrita:

\footnotetext{
"Teus olbo tão singular

Dessas tranģinhas tão preta

Qero morer eim teus braço

Ai fermosa Marieta".
}

Entre todos os erros, o recorrente é o da concordância entre o singular e o plural nos três primeiros versos, como se dissesse que as qualidades comuns de sujeitos múltiplos os unificassem num arquétipo original. Desse modo, os três primeiros versos podem ser lidos assim: dois olhos fundidos num só pelo olhar tão singular, uma cor tão preta que tornava uma só as trancinhas, e a vontade de morrer nos braços unidos num só abraço. $O$ que os aparentes erros queriam enfatizar era a força do traço de união que reduzia a mu ltiplicidade à unidade.

O narrador, como confessa, "vinha vivendo o visto mas vivando estrelas", quer dizer, comungando a sua unidade com a n atureza contemplada, "vivendo o visto" (a alma, como a centelha divina, contemplando as mãos do divino, a sua fonte, no livro da 
natureza), o que animava em si a aspiração ao celeste, "vivando estrelas", como é perceptível na sua escrita, de busca de uma expressão elevada. Em resposta à quadrinha, ele registrou uma fieira de nomes de reis assírio-caldaicos, "rol de reis leoninos", como ele diz, que acordam na memória do leitor, já aturdido com as estranhezas e dificuldades de pronúncia dos nomes, o poder, a riqueza e a luxúria terrena que a sua capital, a Babilônia, simboliza nos dois Livros dos Reis, do Velho Testamento. O que os nomes ressaltam, assim colocados, como em versos, são a força e o poder do homem na terra, mas que se esgotam no tempo. Foram os reis leoninos, na sua sucessão e variedade numérica, os casos extremos de poderio e crueldade, mas que expressam agora a vacuidade, a ausência de espírito e de sentido. Eles podem ser lidos no mesmo ritmo bem marcado dos mantras ou das marchas solenes e marciais, mas repercutindo no fundo os toques surdos das marchas fúnebres, $\mathrm{d} a-$ quilo que se esgota e perece com o tempo: "gon, don, bonid, donosor":

"Sargon
Assarabddon
Assurbanipal
Teglattphalasar, Salmanassar
Nabonid, Nabopalassar, Nabuiodonosor
Belsazar
Sanekherib"

É com esse sentido que o narrador, quando tomado pelo terror pânico, se recorda dos reis e diz: "Os bambús. Os reis, os velhos reis assírio-caldaicos, belos barbaças como reis de baralho, que gostavam de vazar os olhos de milhares de vencidos cativos? São meros mansos fantasmas, agora; são meus".

O que tais nomes despertam no narrador-protagonista é a reflexão e um discurso sobre o poder da palavra, talvez mais do 
que sobre a sua beleza. Se elas podem ser equiparadas aos pássarosanjos, como veremos, "têm canto e plumagem", motivo notado e analisado por Oswaldino Marques ${ }^{15}$, podem também o ser a uma arma, à faca, como algo que acrescenta um poder ao homem: "à parte o sentido prisco, valia o ileso gume do vocábulo" (grifo meu). Tanto se deve recordar as suas origens, recuperar os sentidos arca icos da palavra, "à parte o sentido prisco", como descobrir os novos e nunca tocados, "ileso gume", associando a palavra à arma e dando a ela um poder de separar ou religar o homem e o divino. Ele continua, discorrendo sobre o desacordo entre o som e o se ntido da palavra, observando como o curto e doce nome-pássaro do angelim não descrevia os cinqüenta metros de tronco da enorme árvore indiana, que atirava a sua fronde para cima, e pedia um vocábulo novo, que lhe correspondesse, como a expressão estendida: "Ó colossalidade!" Depois, recorda como não cabia na cabeça do capiauzinho analfabeto Matutino Solferino Roberto da Silva, que a simples palavra "caixote" pudesse conter o biscoito fino, "merc adoria fina", que vinha naquela embalagem, e que deveria ser uma deturpação de algum termo mais difícil, como talxóts. E a seguir, narra quatro casos em que destaca justamente o poder fantástico da palavra. O primeiro, de como um parceiro seu, Josué Cornetas, conseguiu ampliar o espírito de um sujeito raso, "bi-dimensional", ensinando-lhe palavras difíceis, que envolviam conceitos complic ados: "intimismo, paralaxe, palimpsesto, sinclinal, palingenesia, prosopopese, amnemosínia, subliminal". O que a maior parte deles tinha em comum era uma referência a algo que estava oculto, no fundo, por trás, esquecido, subterrâneo. O aprendizado dos co nceitos deu-lhe uma outra dimensão ao espírito, a terceira, a da profundidade. O segundo caso diz como a população do CalangoFrito não gostava do padre Geraldo, porque ele falava fácil e todo mundo entendia, não deixando nada para ser decifrado, portanto, não provocava inquietação nem sugeria profecias, como faziam a 
parábola e o latim que não entendiam. Gostavam mesmo era do defunto padre Jerônimo, que abusava do latim e uma vez, num comício na cidade grande, com uma simples frase, "sub lege libertas?", conseguiu abafar um potente motim iminente. $O$ terceiro caso, conta como o menino Francisquinho, depois de repetir alto quinze ou doze vezes a "toada 'patranha", voltara a ser selvagem. O me smo poder que tinha a palavra de aprofundar o espírito, tinha ta mbém, para quem não soubesse usá-la, de fazê-lo regredir. E, por fim, ele lembra o poder que tinha a frase, "Abre-te Sésamo", de escancarar a porta da "gruta-cofre", talvez sugerindo o poder ta mbém da palavra de abrir outras portas, como as do céu.

Quando ele passou no bambual, no domingo seguinte, o poeta desconhecido, diante da seqüência de nomes dos reis assírios, havia respondido com a frase-comentário:

\section{"Lingua de turco rabatacho dos infernos"}

E continuou o desafio com uma nova quadrinha:

"Na viola do urubú

O sapo chegou no céu.

Quando pego na viola

O céu fica sendo meu ".

A primeira observação do herói-narrador sobre a nova qu adrinha foi esta: "O trovador se esmerara". Agora, sem os "erros" da quadra anterior, essa resposta vinha numa forma aparentemente simples, mas composta num sistema complexo, com uma rima interior cruzada, que não é comum nas composições populares. A viola do início do primeiro verso rima com a viola do final do terceiro e o céu do final do segundo verso rima com o céu do início do quarto. Os dois versos centrais da estrofe, o segundo e o terceiro, 
criam um núcleo forte, com a condensação sonora dos finais de duas palavras do segundo, "sapo chegou", numa palavra do terce iro, que funde as sílabas finais de sapo e de chegou: pego. E finaliza com o pronome possessivo meu, que repercute os ús finais do primeiro e do terceiro versos. Quanto ao tema, ela camufla também atrás de uma história banal e popular, a do urubu e do sapo que vão de contrabando numa festa do céu, um assunto elevado, o do trânsito entre o celeste e o terreno, de tal modo que os bichos repulsivos, o urubu das carniças e os sapos dos pântanos, chegam ao céu, e conclui com o cantor, levianamente, tomando posse dele: " $\mathrm{O}$ céu fica sendo meu". O complexo estava assim oculto por trás do aparentemente simples, com o céu invadido por seres terrenos em excesso, usando para isso as vias não-regulares, e sendo apropriado pelos versos do violeiro, trazendo-o para a terra: "o céu fica sendo meu".

O comentário do narrador-protagonista, percebendo a el aboração e a profundidade da mensagem, dá ao poeta desconhecido um nome que é uma meia pergunta, "Quem-será", com hífen e sem a interrogativa, e torna-o no seu "melhor amigo", talvez por tratar das questões que são as de sua preocupação. Depois, respo nde, continuando o desafio:

"Tempo de festa no céu,

Deus pintou o surucuá:

com tinta arul e vermelba,

verde, cinzenta e lilá.

Porta de céu não se fecha:

surucuá fugiu pra cá. ".

Ao contrário do urubu, pássaro sem cor e carniceiro (o oposto das garças brancas, que representam as Graças, os urubus representam as Erínias), além disso, despudorado, pois entra no 
céu de cabeça pelada e descoberta, o surucuá é uma criatura celeste, pintada por Deus, que foge para a terra. De um modo ou de outro, são as aves que fazem a intermediação entre o céu e a terra, páss aros-anjos, como os joões, homônimos do autor. Só que o surucuá foi pintado e ornamentado por Deus, que o transformou num dos mais belos do mundo. Rodolpho von Ihering, no Dicionário dos Animais do Brasil, assim o descreve: "Há uma espécie, do gênero Pharomacrus, amazônica, que ultrapassa os demais surucuás em beleza, a ponto de ser uma das aves mais lindas do mundo. A espécie mais conhecida desta família é a da América Central e do México, aí denominada 'Quetzal'“'16. Ave que tem um alto valor simbólico na cultura azteca e maia. ${ }^{17}$ Reunindo no seu nome o som e o sentido, Surucuá, a beleza do som da palavra e do ser a que se refere, ele veio como uma doação e um mensageiro, angelous, para os homens, portanto, para ser contemplado e entendido, cujo recado ele escreve a seguir:

\footnotetext{
"Tem o teu e tem o meu

tem canhota e tem direita,

tem a terra e tem o céu -

escolba deve ser feita?"
}

O narrador-protagonista não gosta da forma do final da própria mensagem, já bem explícita e pouco poética. Porém ela fala da escolha que deve ser feita entre o céu e a terra, associando o caminho da direita com o do céu e o da esquerda com o da terra; e, como num desabafo, torna-a mais explícita ainda, como se dissesse que havia só uma alternativa válida, a da busca do celeste e da perfeição: 
A outra escolha era a da "pândega", a festa terrena dos comes e bebes, de encher a pança, e que lembra a primeira das três árvores que analisaremos adiante, à qual ele pensa levantar "uma estatueta e um altar a Pan". O verdadeiro recado passava a ser então o de que não havia alternativa à busca da perfeição e do celeste, cultuada pela poesia clássica, embora esta sempre estivesse ameaçada pelas forças terrenas do baixo e do grotesco de Pan, que vivia a desafiar a lira de Apolo, com a sua gaita de sete canudos, sýrinx, não esquecendo que é o instrumento de sopro, a flauta, que imita os sons da flatulência ${ }^{18}$.

No domingo seguinte, ele encontrou a resposta:

“Chegando na encruzilhada

eu tive de resolver.

para a esquerda fui, contigo.

Coração soube escolber?"

Embora Quem-será dê a entender que acompanhou o seu desafiante na escolha, quando chegaram na encruzilhada, "para a esquerda fui, contigo", na verdade, o narrador-protagonista tinha tomado o "carreador da direita", na bifurcação do caminho, onde ele havia se encontrado com o Aurísio Manquitola, Cronos/Saturno, o tempo portador da foice implacável, como diz ele, "arma de su stância - só faz conta de somar! Para foice não tem reza, moço...", e que, depois de contar-lhe a série de casos, dele se separou, indo para o outro lado, o da esquerda. Desse modo, se entende que Quem-será acompanhou na verdade o Aurísio Manquitola, o te mpo da Terra e da morte, deixando-se guiar pelo coração, "coração soube escolher", pressupondo que o narrador tenha-se guiado pela razão e vontade do celeste, indo pela direita. $\mathrm{O}$ que ele reconhece como triunfo de Quem-será e a sua derrota, pelo menos no des afio. 
A partir dai, o herói-narrador deixa o bambual e vai se enfurnando na mata. A descrição que nos dá dessa descida é a de um espírito que vai se inebriando e, com isso, tendo a visão de tudo transfigurada, cujos efeitos são passados ao leitor pela disseminação de termos humanos nas descrições que faz dos aspetos da flora, como se a visse encantada por seres antropomórficos, feéricos e sedutores. Este procedimento é importante de ser observado, pois ele se repetirá adiante, mas com significações que vão além dos efeitos estéticos e psicológicos que provocam no protagonista, e se referem mais à ordem de preocupações do autor do que às do herói-narrador. $O$ mesmo que acontece no micro, também se proce ssa no macro, ou seja, o autor vai semeando ao longo de toda a história elementos que visam a sugerir ao leitor que tudo aquilo tem também uma dimensão mítica e cósmica. Desse modo é instrutivo apreciar este trecho:

"Mas, as imbaúbas! As queridas imbaúbas jovens, que sào toda uma paisagem!... Depuradas, esguias, femininas, sempre suportando o cipó-braçadeira, que lhes galga o corpo com espirais constrictas. De perto, na tectura sóbria - só três ou quatro esgalhos - as folhas são estrelas verdes, mãos verdes espalmadas; mais longe, levantam-se das grotas, como chaminés alvacentas; longe-longe, porém, pelo morro, estào moşas cor de madrugada, encantadas, presas, no labirinto do mato" (os grifos são meus).

Os termos usados, como "jovens", "femininas", "corpo", "mãos", "moças", são todos do campo do humano, mas vão sendo disseminados pelo texto referindo-se à vegetação, de modo a nos sugerir que se trata de uma floresta encantada. Assim, o que pod eria ser um passeio comum, vai se transformando numa aventura fantástica e com riscos. Perigos que se acentuam, quando ficamos sabendo, no final do período, que ele penetra "no labirinto do 
mato". E é por esses meandros povoados de seres femininos fantásticos, descritos por termos que lembram as rezas encantatórias, que ele chega a um espaço em tudo identificado como o lugar do sagrado. Elementos, números, formas e disposição, tudo indica ter sido ali um lugar arranjado pela própria natureza para fazer confluir e propiciar o encontro com as forças do divino: “...lá embaixo, as águas das Três-Águas. Três? Muitas mais! A lagoa grande, oval, tira do seu pólo rombo dois córregos, enquanto entremete o fino da cauda na floresta".

É lá também que a vida prolifera, demorando-se a narrativa em longas enumerações de plantas da flora brasileira de nomes sonoros, que, na nossa literatura, o que temos de mais próximo são as enumerações do Macunaima, que por sua vez recordava passagens do Iracema, mas aqui adquirem outros sentidos e provocam outras sugestões. A partir das características do lugar, o narrador vai semeando indicações de penetração num espaço labiríntico, como o construído por Dédalo, "três sendas dedalinas", guardado por "á rvores, adiantadas sentinelas", como um caminho de iniciados, "o estado de alma do crente", e de escolhas simbólicas, "escolhi a trilha B", a do meio, com uma finalidade de iniciação e penetração nos mistérios: "Aqui, convém: meditar sobre as belezas da castid ade, reconhecer a precariedade dos gozos da matéria, e ler a história dos Cavaleiros da Mesa Redonda e da mágica espada Excalibur". Porém, o lugar não só está carregado de presenças místicas, como também de ameaças psicológicas e físicas, que podem se conjugar para produzir o pânico: "Mas não posso demorar. A frialdade do recanto é de gripar um cristão facilmente, e também paira no ar finissima poeira de lapidação de esmeraldas, que deve ser asmatizante" (grifos meus). Esta passagem é importante para se esclarecer como o autor procura combinar elementos místicos e naturais, com certo equilíbrio, de modo a que os fatos posteriores possam tanto encontrar uma explicação de ordem extraordinária quanto ordinária. 
Na cabeceira da lagoa e presidindo o lugar, estão três clare iras, tendo em cada uma, como "dona destacada", três "árvores tutelares". Foi aí que, pela primeira vez, Guimarães procurou representar num conjunto a sua teoria dos três amores. Ali estão reun idos os três arquétipos fundamentais que regeriam as várias dimensões da experiência amorosa. Eles aparecem como três árvores imensas na cabeceira da lagoa oval e especular. As árvores estão assim descritas:

"Agora vamos retroceder, para as três clareiras, com suas respectivas árvores tutelares; porque, em cada aberta do mato, há uma dona destacada, e creio mesmo que é por falta de sua licença que os outros paus ali não ousam medrar.

"Primeiro, o 'Venusberg' - onde impera a perpendicularidade excessiva de um jequitibá-vermelho, empenujado de liquens e roliço de fuste, que vai liso até vinte metros de altitude, para entào reunir, em raqueta melhor que em guarda-chuva, os seus quadrangulares ramos. Tudo aqui mandar pecar e peca desde a cigana-do-mato e a mucuna, cipós libidinosos, de flores poliandras, até os cogumelos cinzentos, de aspirações mui terrenas, e a erótica catuaba, cujas folhas, por mais amarrotadas que sejam, sempre voltam, bruscas, a se retesar. Vou indo, vou indo, porque tenho pressa, mas ainda hei de mandar levantar aqui uma estatueta e um altar a Pan. ${ }^{19}$

"Um claro mais vasto, presidido pelo monumento perfumoso da colher-de-vaqueiro, faraônica, que mantém à distância cinco cambarás ruivos, magros escravos, obcônicos, e outro cambará, maior, que também vem afinando de cima para baixo. Puro Egito. Passo adiante.

"Agora, sim! Chegamos ao sancto-dos-sanctos das Três Águas. A suinã, grossa, com poucos espinhos, marca o meio da clareira. Muito mel, muita bojuí, jati, urussú, e toda raça de 
abelhas e vespas, esvoaçando; e formigas, muitas formigas marinhando tronco acima. A sombra é farta. E há os ramos, que trepam por outros ramos. $\mathrm{E}$ as flores rubras, em cachos extremos - vermelhíssimas, ofuscantes, queimando os olhos, escaldantes de vermelhas, cor de guelras de traíra, de sangue de ave, de boca e bâton". ${ }^{\prime \prime}$

A primeira árvore representa o amor puramente carnal e fálico, masculino, de um monte de Vênus penetrado por um enorme falo, "um jequitibá-vermelho, empenujado de liquens e roliço de fuste", como um amor instintivo de satisfação sexual, "Tudo aqui manda pecar e peca", reproduzindo no seu entorno uma prolifer ação de formas e traços do órgão masculino: cipós libidinosos, flores poliandras, cogumelos cinzentos, "de aspirações mui terrenas, e a erótica catuaba, cujas folhas, por mais amarrotadas que sejam, sempre voltam, bruscas, a se retesar". É a procura da ereção ince ssante e que nada difere da sexualidade animal, sendo diante dela que ele pensa mandar levantar "uma estatueta e um altar a Pan". O mesmo deus, cujo nome ressoa na alternativa à "perfeição", a pândega, e que provoca o pânico, o terror pânico, comum nos que penetram nas matas fechadas, cujo isolamento causa o medo e a pe rda de controles que se acreditava provocados pelo deus. ${ }^{21}$

A segunda árvore, feminina por excelência, no nome, no comportamento e na forma, que lembra a da concba, colher-devaqueiro, descrita como "monumento perfumoso", que seduz e rejeita ao mesmo tempo, tendo os seus escravos também formas femininas, de vulvas, "obcônicos", que são mantidos à distância. Além das referências, "monumento perfumoso" e "faraônica", o Egito é diretamente mencionado para indicar o que ela lembra: "Puro Egito". Ele é a região simbolizada como a pátria da sensual idade e do amor sensível, foi o que ele passou a significar depois do cativeiro dos hebreus na história de José. O amor puramente hu- 
mano, desenvolvido como cultura e arte, voltado para satisfazer os sentidos, que atiça e delicia a todos eles: vestimentas e nudez, ornamentos e pinturas para a vista; perfumes e incensos para o olfato; sonoridades e cantos para os ouvidos; iguarias afrodisíacas para o paladar; e as mais variadas posições para maior satisfação do tato, transformando todas as partes do corpo em regiões eróticas e se nsuais, de tal modo que o corpo inteiro se transforma em sexo. A arte do amor já não seria mais animal, mas também não transce nderia, não implicaria em futuro nem em imortalidade ou o que permitisse ao homem a aspirar ao divino.

A terceira árvore representaria o próprio amor gerador e fecundo, estaria além do masculino e do feminino, borbulha de doçura e símbolos da geração, a vida inteira girando em torno dela, como um culto da sua fonte. A grande árvore vermelha, como á rvore geratriz da vida, contém em si o masculino e o feminino, é inteira e possibilita a continuidade de tudo, por isso transcende, traz futuro, permanência e imortalidade, o que a faz ser merecedora de um outro culto, diferente do de Pan: "Mas a grande eritrina, além de bela, calma e não-humana, é boa, mui bondosa - com ninhos e cores, açúcares e flores, e cantos e amores - e é uma deusa, portanto". E será nela que o narrador-protagonista se encostará para descansar ${ }^{22}$.

Diante dele, ficava a lagoa oval, como o ovo primordial, fonte de tudo, de vida e de morte ${ }^{23}$, e que reunia também em si o que se multiplicava fora dela, estendendo-se como um espelho onde se reproduzia a natureza exuberante. Além de refletir o que lhe era exterior, aparecendo tudo invertido, "tomando um banho verde”, ela continha em si uma vida própria, de peixes, pássaros aquáticos, insetos e cisqueira, inclusive o herói, como um "joãogrande, contemplativo, ao modo em que eu aqui estou, sob a minha corticeira de flores de crista-de-galo e coral", como se fosse o seu próprio reflexo. E tudo ainda se desdobrava com a luz do sol 
refletindo na lagoa e dividindo-a em duas, metade a metade, " $\mathrm{E}$ a lagoa parece dobrada em duas, e o diedro é perfeito", quebrada em dois planos, um de luz e outro de sombra, como o ovo, fonte de vida e de morte. Repetem-se aqui as enumerações marioandradinas, do Macunaíma, agora com nomes de pássaros e insetos, de modo a explorar com as suas sonoridades a riqueza da vida bo $\mathrm{r}$ bulhante e os movimentos que a animavam. Foi nesse momento, quando o herói-narrador passava da contemplação da vida intensa e exuberante concentrada na lagoa para um estado de sonolência $e$ distensão, "Paz", que ele foi tomado pelo terror pânico:

"E, pois, foi ai que a coisa se deu, e foi de repente: como uma pancada preta, vertiginosa, mas batendo de grau em grau - um ponto, um grão, um besouro, um anú, um urubú, um golpe de noite... E escureceu tudo".

Para ele, a possessão não significou a perda da consciência e dos demais sentidos, tornando-se no inteiramente outro, deus ou entidade possessiva, mas somente a cegueira, metaforizada pelos elementos negros: ponto, grão, besouro, anu, urubu, noite. Porém, significava, mais do que a perda da capacidade de ver, também a de contemplar, de olhar com a alma: "Era a treva, pesando e compr imindo, absoluta". Foi a perda dessa possibilidade religiosa de transcender os sentidos através de um deles, o da visão, que o to rnou num Zé ninguém, num pobre diabo ${ }^{24}$. Assim como ele continuava acordado, consciente, pensando, raciocinando e calculando, todos os demais sentidos também continuavam despertos e se aguçavam, mas não eram capazes de guiá-lo, ao contrário, quando tentou se orientar por eles, pelo tato, pelos cheiros, pelos sons, e até deixando-se levar pelo instinto e pelos próprios pés, "Pé por pé, pé por si. Deixarei que o caminho me escolha", como um ZéPrequeté, perequeté, piriqueté, conforme sua acepção também, no 
Norte, de sandália de índio, chegou muito perto de se perder, nos dois sentidos. No metafórico-espiritual, quando foi visto como um pândego, abandonado pelos protetores celestes, a suinã e os páss aros:

"Uma cigarra sissibila, para dizer que estou cômico. Fêz-me bem. Mas onde estarei eu, aonde foi que vim parar? Pior, pior. Perdi o amparo da grande suinã. Perdi os croticos das criaçòes de pena da lagoa. E aquir? Este lugar é caminbo de vento, e dos rumores que o vento traz: 0 sabrasil, à brisa, atrita as rendilhas das grimpas; as frondes do cangalbeiro farfalham; as palmas da palmeira-leque aflam em papelada; e - pá-pá-pá-pá - o pau-batecaixa, golpeado nas folhas elásticas, funciona eloqüente" (os grifos são meus).

Como no trecho das árvores-moças, o herói-narrador, descrevendo a sua situação, dissemina aqui uma série de signos que remetem à idéia de pândega e de vacuidade. Perdido e sendo apreciado pela cigarra como "cômico", situa-se num lugar onde domina o vento e que é descrito por termos que remetem a muitos estereótipos utilizados como símbolos de caráter, identidade e nacion alidade: "cigarra", "cômico", "caminho de vento", "sabrasil", "ca ngalha", "palmeira", "eloqüente". O mais significativo talvez seja o sabrasil, possivelmente se refira ao sobrasil, árvore das rubiáceas, para falar dos rumores do vento nas suas folhas lanceoladas. Esse termo composto com o próprio nome do país resume um espaço abstrato e ideológico em que se encontraria perdido numa perspectiva cômica, cego e sem orientação, como o homem cordial, movido pelo coração. O que o lembrava do Quem-será e os seus versos, que cita nessa passagem: "para a esquerda fui, contigo./ Coração soube escolber": 
E perdido também no sentido físico, literal: "Então, e por caminhos tantas vezes trilhados, o instinto soube guiar-me apenas na direção pior - para fundões da mata, cheia de paludes de águas tapadas e de alçapões do barro comedor de pesos?!...” Foi quando, sentindo-se à beira do abismo e do desespero, já apelando para Deus e o Diabo, é que ouviu pela terceira vez o alerta: "Guenta o relance, Izé"...

A primeira vez, tinha sido ainda antes de passar pela tapera do João Mangolô, quando ouviu a exclamação e percebeu que não era com ele, mas com outro Zé, que ele chamou de "meu homônimo", ao cair do cavalo: "Zé-Prequeté, que, trinta metros adiante, se equilibrava em cima dos saltos arqueados de um pangaré ne urastênico". A segunda vez que a ouviu, foi quando já tinha sido tomado por Pan e que ele entendeu como um chamado: "Uma ordem. Enérgica e aliada, profunda, aconselhando resistência”. Só que agora, era ele próprio o José. Como nos ritos de passagem, ele tinha mudado de nome: com a perda da capacidade contemplativa, transformou-se num Zé-Prequeté, figura do populário e que tem justamente essa acepção, a de Zé-ninguém, pobre diabo. $\mathrm{E}$ agora, na terceira vez que ouvira o alerta, "Guenta o relance, Izé", como na primeira vez, estava por perto o Aurísio Manquitola, aquele que respeitava a reza-brava e contara-lhe os casos sobre o seu poder: "um longínquo Aurísio Manquitola, brandindo enorme foice", e que gritava: “Tesconjuro! Tesconjuro!”...

Talvez não seja por acaso que essa mesma figura do Zéninguém aparece em Oswald de Andrade e Mário de Andrade. No primeiro, ele aparece no Primeiro Caderno do Alumno de Poesia, no poema "enjambement do cozinheiro preto":

"Chamava-se José

José Prequeté

A sua habilidade consistia em matar de longe 
Decepando com uma larga e certeira faca

Cabeças

De frangos, patos, marrecos, perus, enfim

Da galinhada solta no quintal

Do Grande Hotel Melo"25

Em Mário, ele aparece no Macunaima, quando o herói, ao virar uma esquina encontrou o José Prequeté e gritou pra ele:

“- Zé Prequeté, tira bicho do pé pra comer com café!

José Prequeté ficou com ódio e insultou a mãe do herói

porém este não fez caso não, deu uma grande gargalhada e foi seguindo".26

Tanto para um como para outro, o Zé-ninguém era o outro, seja o cozinheiro negro seja o Prequeté da expressão popular. Mas, aqui, era o próprio narrador-protagonista que havia se transform ado nele, procurando, portanto, descrever de dentro, do seu interior, as sensações e impressões da vida nas trevas, do homem cativo dos sentidos e dos impulsos, sem a capacidade de visão e contemplação, tomado inteiro pelas forças terrestres da fome, "da pança", como os Prequetés dos modernistas: um era o cozinheiro que matava as aves atirando de longe a faca e o outro vivia a comer bicho do pé. Duas figuras da pândega modernista.

Foram as palavras do Aurísio Manquitola, o Tempo, que o salvaram, lembrando-o da reza-brava de São Marcos, o segundo elemento da credulidade daquela gente de que havia zombado, mas que tinha um sentido oposto ao da feitiçaria do João Mangolô: a reza buscava o domínio e a submissão das forças demoníacas ou dionisíacas da natureza, representada pelo touro bravo. A reza de São Marcos falava de como o santo conseguira domar o touro e levá-lo manso à igreja para adorar a Jesus Cristo: “o boi de São 
Marcos (25 de abril) levado aos templos, assistindo a missas perto do altar-mor, acompanhado pelos fiéis numa devoção indiscutivel". E ela começava assim: “...touro brabo, assim com São Marco foi ao pé da serra buscá os touro brabo e os trouxe manso e pacífico atrás de si: à sua vontade e ao seu querer, assim vou eu F... te buscá e hei de te trazê manso e pacífico atrás de mim, à minha vontade e ao meu querê". ${ }^{27}$ A reza foi o bastante para o herói ser ajudado por uma outra força, mais poderosa, que o carregou e conduziu até a casa do feiticeiro/Meleagro: "Grunhos de porcos. Os porcos do João Mangolô".

Ao enfrentá-lo e espancá-lo, “queria, precisava de exterminar o João Mangolô", tudo se tornava claro novamente à sua volta, "Luz, luz tão forte", e com isso se sentia glorioso. O safanão final e a derrota do feiticeiro são descritos como a vitória sobre as forças terrenas ou a própria Terra, referida aqui como um astro menor, sem luz e calor próprios, uma dançarina submissa e dependente, que deveria girar eternamente em torno do seu verdadeiro senhor, o Sol, astro maior: "Outro safanão, e Mangolô foi à parede e voltou de viagem, com movimentos de rotação e translação ao redor do sol, do qual recebe luz e calor" (grifos meus).

A vitória, no plano do prosaico, termina também com as explicações do feiticeiro e a sua submissão. O herói, por sua vez, dá uma demonstração de grandeza e magnanimidade: propôs um acordo com o feiticeiro e pagou-lhe com dez mil-réis o feitiço de que tinha sido vítima, como uma solução de compromisso (inclus ive da religião com a magia): “- Olha, Mangolô: você viu que não arranja nada contra mim, porque eu tenho anjo bom, santo bom e reza-brava... Em todo o caso, mais serve não termos briga... Gua rda a pelega. Pronto!"

Mas ainda não era o fim da história. Ela só termina depois que o narrador nos mostra a sua confirmação como João, o sujeito que era desde o início da história, com a recuperação da sua capa- 
cidade de contemplar: "Mas recobrara a vista. E como era bom ver!'. De certo modo, ele se livrava do estigma que estava inscrito na epigrafe, que falava de uma visão turva das coisas, própria de quem vivia no engano, e que confundia o homem com o coco, o coco com a creca do macaco, a creca com o macaco inteiro e assim por diante, até o fim das coisas. Portanto, a visão a que se referia, era a da alma e da mente, capaz de ver uma verdade simbólica que estava para além das aparências dos objetos, e que, numa outra interpretação da epígrafe, equivalia a escapar da visão onde nada era fixo e tudo poderia se transformar em tudo. Assim, ver, era chegar às representações simbólicas e essenciais das coisas, mas que só se revelavam aos crentes ou iniciados e na sua linguagem própria, na forma de hieróglifos ou brasões. A história se iniciara com a visão de uma representação solar, descrita de modo paratático, no estilo usado para se descrever os brasões medievais, com a justaposição de campos, cores e figuras alegóricas hierarquizadas e estilizadas:

"No céu e na terra a manhà era espaçosa: alto azul, gláceo, emborcado; só na barra azul do horizonte estacionavam cúmulos, esfiapando sorvete de côco; e a leste subia o sol, crescido, oferecido - um massa-mel amarelo, com favos brilhantes no meio a mexer".

Nesse brasão, o Sol era alegorizado como a fonte geradora de luz, calor e abundância, mel e favo, que alimentava uma terra que, se abandonada a si própria, só conheceria o frio gláceo e prosaico do sorvete. E a novela se encerra com uma outra visão, ep ifânica, de quem olhava também para cima e o celeste, mas agora descrita como um novo brasão, lunar:

“ $\mathrm{Na}$ baixada, mato e campo eram concolores. No alto da colina, onde a luz andava à roda, debaixo do angelim verde, 
de vagens verdes, um boi branco, de cauda branca. E, ao longe, nas prateleiras dos morros cavalgavam-se três qualidades de azul".

Agora, esse brasão fechava a história da sua provação e co nfirmação, porém não sem antes ter estabelecido um compromisso com as forças que o ameaçavam, João Mangolô, depois de derrotálas. A visão derradeira é a de uma imagem redentora da lua na col ina, "a luz andava à roda", do angelim verde, a árvore indiana, cujo nome doce e de mensageiro não exprimia toda a sua colossalidade, e o boi branco, símbolo alto e traço sagrado que nos reunia à trad ição Veda, boi do Brasil e da Índia. A reza-brava era um vínculo bom a ser incorporado, pois era onde a palavra ganhava maior p oder de domar as forças telúricas ameaçadoras e de realizar a ligação com o divino, assim como o boi, que nos ligava à Índia e à tradição mais antiga das religiões organizadas da Antigüidade. Não era mais o boi nacional de Mário de Andrade, o traço móvel de união do país, que transitava por todos os sertões e rios, ultrapassando as marcas regionais. Era agora um outro boi que se apresentava como alternativa ao boi do bumba-meu-Boi, do final do Macunaima, e ao boi Paciência, do poema "Brazão", que recordava também a or igem do nome do país ("em zarcão ardendo", como a brasa do paubrasil), onde ele fala, entre outras coisas, de um filho de mestre do Catimbó, como o João Mangolô, o Mestre Carlos ${ }^{28}$, que aparece também em outros poemas, como no "Poemas da Negra": "Há em ouro a arca de Noé com vinte-e-nove bichos blau,/ E a Jurema esfolhando as folhas derradeiras/ Sobre Mestre Carlos, o meu grande sinal", e que não posso deixar de citar a continuidade, por conter outros pontos comuns com a novela:

"E falta o boi Paciência, o boi que pertence a Armida, Traz por guampas os cornos da luna 
E um peitoral de turmalinas.

Mas esse vem no outro coração mole,

Nào se mostra a ninguém.

O boi Paciência serào treze preguiças assustadas,

No porto do imenso rio esperando,

Esperando pelos treze caminhos

Das mil cavernas das quarenta mil perguntas ${ }^{29}$,

Muitos aspectos, assim como muitas referências, do poema e da novela são semelhantes, além dos traços estilísticos e narrativos: "estrela dos treze bicos" e "treze consoantes alternadas com treze pontos"; "coração mole" e "coração soube escolher"; "Mestre Carlos" e "João Mangolô"; "eu que escolhi" e "soube escolher"; "Que-dele eles" e "Quem-será"; "boi paciência" e "boi branco"; “os cornos da luna" e "a luz andava à roda". Conta também o fato de os mestres do catimbó aparecerem em ambos com o sinais de valor trocados: positivo no poema e negativo na novela, como se esta estivesse respondendo aquele ${ }^{30}$. Parece-me que os pontos comuns mencionados acima são mais do que coincidentes, já que muitos deles vinham ocupando um papel importante na obra de Mário de Andrade há tempo. O fato pode revelar uma procura por parte de Guimarães de até onde seria possível o diálogo, a assimil ação e o compromisso, além do modo próprio de concretizá-los, com uma profunda alteração de sentido ${ }^{31}$. O boi de Mário criava um símbolo de unidade cultural e nacional, um traço de união que soldava e identificava, superando as características regionais, constituindo-se num brasão positivo e dionisíaco que trazia uma esperança regeneradora. Assim, o Macunaima tinha tanto uma perspectiva desmistificadora das tendências ufanistas da época, quanto, como Iracema e O Guarani, propunha-se também como um novo mito de fundação ${ }^{32}$. Para Guimarães Rosa havia um touro e um boi. O primeiro, como força da natureza e da desordem que preci- 
sava ser domada e submetida pela reza poderosa de São Marcos, reza assimilada e local, que nos salvava das ameaças desordenad oras, igualmente locais, mas com quem tínhamos de conviver. $\mathrm{E}$ o boi, fato do país e símbolo, que radicava o local na mais antiga tr adição religiosa indo-européia, na tradição Védica, o que poderia nos dar universalidade e remeter ao celeste. $\mathrm{O}$ boi do brasão de Guim arães era o de quem escolheu a contemplação do universal e do divino no caminho da perfeição, tendo porém que transitar pelos caminhos do vento e da pândega, os riscos da travessia com o $\mathrm{Au}$ rísio Manquitola, o Tempo, mas que também podia nos salvar. ${ }^{33}$

\section{Notas}

1 A divisão entre um "primeiro" e um "segundo" Guimarães pode ser apreciada tanto a partir dos aspectos literários das obras, como das suas motivações externas, correspondendo o "primeiro Guimarães" aos livros escritos durante o chamado período getulista da nossa vida política, de 30 a 54; sobre essas relaçòes mútuas do fato histórico com o fato literário discorrerei num outro lugar do meu trabalho.

2 Cf. João Luiz Lafetá, 1930: A Critica e o Modernismo, São Paulo, Livraria Duas Cidades, 1974

3 Sobre a importância da funçào decifratória do crítico no trato com o texto literário v. Victor Knoll, Paciente Arlequinada, São Paulo, Hucitec/SECSP, 1983; Gilda de Mello e Souza, "Apresentação", in Mário de Andrade: melhores poemas, São Paulo, Global Editora, 1988; José Antonio Pasta Júnior, no ensaio, "O romance de Rosa: Temas do Grande Sertão e do Brasil", chama a atençào para a necessidade de se dar conta, ao mesmo tempo, das duas demandas do romance, enquanto enigma e enquanto mistério. Essa observação, creio eu, deve valer para o conjunto da obra de Guimarães: "Tudo se passa como se, por sua constituição mesma e pelo pacto que firma com seu leitor, esse livro transcendesse a categoria estético-literária do enigma, que no entanto é a sua, para tender àquela, mágico-religiosa, do mistério. Como se sabe, enigmas pedem 
decifração; mistérios admitem apenas culto e celebração. O Grande Sertão : Veredas parece pedir ambas as coisas e, de modo menos ou mais sutil, não é raro ver-se, diante dele, o ofício do crítico desdobrar-se na celebração do oficiante [...]. Vistas as coisas pelo ângulo dos gêneros e das formas literárias, pode-se dizer que, quem quiser de fato ler o Grande Sertão guardando fidelidade à demanda do livro, terá que lê-lo ao mesmo tempo com o isolamento e a distância que supõe o romance moderno e com o fusionamento e a participaşão que, no limite, só conhecem o mito e o rito". (Centre de Recherche sur les Pays Lusophones CREPAL, Cahier No. 4, outono de 1997, pp. 159-160) 4 "Por outro lado, como ficou sugerido, a região deixando de ser, para ele, simples localização da história, com funções de pitoresco e anedótico, passa a verdadeira personagem (se assim me posso exprimir), tanta é a persistência e a profundidade com que vêm invocados a sua flora, a sua fauna, o seu relevo. Há, mesmo, certos contos, como “Sào Marcos”, em que só ela redime o anedótico e garante o toque literário autêntico". Antonio Candido, "Sagarana", in Eduardo de Faria Coutinho, Guimarães Rosa, Fortuna Crítica 6, Rio de Janeiro, Civilização Brasileira, 1983, p. 246

5 As citações da novela foram feitas da $14^{a}$ ediçào, comemorativa do jubileu de prata de Sagarana, Rio de Janeiro, José Olympio, 1971, pp. 224-255, e cotejadas com a primeira edição de Sagarana, Rio de Janeiro, Editora Universal, 1946, 209-235.

6 Escrevendo a João Condé sobre Sagarana, Guimaràes diz: “Àquela altura, porém, eu tinha de escolher o terreno onde localizar as minhas histórias. Podia ser Barbacena, Belo Horizonte, o Rio, a China, o arquipélago de Neo-Baratária, o espaço astral, ou, mesmo, o pedaço de Minas Gerais que era mais meu. E foi o que preferi. Porque tinha muitas saudades de lá. Porque conhecia um pouco melhor a terra, a gente, bichos, árvores. Porque o povo do interior - sem convenções, 'poses' - dá melhores personagens de parábolas: lá se vêem bem as reações humanas e a ação do destino: lá se vê bem um rio cair na cachoeira ou contornar a montanha, e as grandes árvores estalarem sob o ráio, e cada talo de capim humano rebrotar com a chuva ou se estorricar com a seca". In Vilma 
Guimaràes Rosa, Relembramentos: João Guimarães Rosa, meu pai, Rio de Janeiro, Nova Fronteira, 1983, p. 333.

7 Creio ser importante observar como o processo de simbolização desenvolvido por Guimarães é distinto do de Baudelaire. Se este constrói suas representaçòes simbólicas a partir de fatos do prosaico, um cisne sedento no aviário de uma antiga praça de Paris se transforma, na poesia, numa alegoria da agonia do sujeito na sociedade burguesa moderna; Guimarães parece partir do símbolo culto, fazendo-o renascer no prosaico, travestido e aclimatado às circunstâncias do presente. Observe-se como, nesta história, a figura e o nome de um capiau, Aurísio Manquitola, servem para revestir a presença de Cronos/Saturno. Sem a percepção desta dimensão culta da representação, o interesse da história ficaria restrito ao pitoresco-regionalista.

8 Reconhece na concepção contemplativa de Guimarães uma mistura de cristianismo, filosofia renascentista - a contemplação passando pelos sentidos, ainda que seja pelo mais divino deles, o da visão - e aristotelismo, este muito menos apontado que o platonismo pelos estudiosos do autor. No entanto Aristóteles parece estar patente nesta novela nào só na idéia de contemplação, mas em várias outras concepções elaboradas aqui $\mathrm{e}$, inclusive na sua orientaçâo geral. Citarei alguns trechos de Aristóteles que nos ajudarão a compreender muito da dimensão conceitual trabalhada e exposta artisticamente na obra:

"Pensa-se que a vida feliz é conforme à excelência; então a vida conforme à excelência requer diligência e nào consiste em entretenimentos. E dizemos que as coisas sérias são melhores que as coisas risíveis e que as relacionadas com o entretenimento, e que quanto mais nobre é uma faculdade ou uma pessoa, tanto mais sérias, pensamos nós, sào as suas atividades; logo, a atividade da faculdade ou da pessoa mais nobre é superior em si, e portanto mais apta a produzir a felicidade.

“Qualquer pessoa pode igualmente fruir os prazeres do corpo, seja ela quem for, e um escravo nào menos que o melhor dos homens, mas ninguém atribui a um escravo um quinhào de felicidade, a não ser que se lhe atribua também um 
quinhão de vida livre. Portanto a felicidade não consiste em passatempos e entretenimentos, e sim em atividades conformes à excelência [...]

“7. Mas se a felicidade consiste na atividade conforme à excelência, é razoável que ela seja uma atividade conforme às mais alta de todas as formas de excelência, e esta será a excelência da melhor parte de cada um de nós. Se esta parte melhor é o intelecto, ou qualquer outra parte considerada naturalmente dominante em nós e que nos dirige e tem o conhecimento das coisas nobilitantes e divinas, se ela mesma é divina ou somente a parte mais divina existente em nós, então sua atividade conforme à espécie de excelência que lhe é pertinente será a felicidade perfeita. Já dissemos que esta atividade é contemplativa [...]

"Mas uma vida como esta seria demasiadamente elevada para o homem, pois nào seria como homem que ele viveria assim, mas como se algo divino estivesse presente nele; e esta atividade [a contemplaçào] é superior às outras formas de excelência na mesma proporção em que este "algo divino" é superior à nossa natureza heterogênea. Entào, se o intelecto é divino em comparaçào com as outras partes do homem, a vida conforme ao intelecto é divina em comparação com a vida puramente humana. Ma nào devemos seguir aquelas pessoas que nos instam a, sendo humanos, pensar em coisas humanas, e sendo mortais, a pensar no que é mortal; ao contrário, devemos tanto quanto possivel agir como se fôssemos imortais, e esforçar-nos ao máximo para viver de acordo com o que há de melhor em nós, pois embora esta nossa parte melhor seja pequena em tamanho, em poder e importância ela utrapassa todo o resto. E pode realmente parecer que esta parte é a verdadeira natureza de cada criatura humana, já que ela é a sua parte dominante e melhor. Seria estranho, com efeito, se o homem devesse dar preferência não a viver a sua própria vida, mas a vida de outro ser qualquer. E o que dissemos antes se aplica agora: aquilo que é peculiar a cada criatura lhe é naturalmente melhor e mais agradável; para o homem, a vida conforme ao intelecto é melhor e mais agradável, já que o intelecto, mais que qualquer outra parte do homem, é o homem. Esta vida, portanto, é também a mais feliz". Ética a Nicômacos, $3^{\text {a }}$ ed., trad. de Mário da Gama Kury, Brasí- 
9 Roger Bastide apresenta uma variaçào desses mandamentos acompanhada de comentários que podem nos ajudar a compreender alguns aspectos da questão: "A estrutura social do Brasil escravista, separando as cores em classes superpostas, cada qual com a sua civilização própria, levou a uma falsificação de seus respectivos valores./ $O$ branco não podendo compreender uma religião tão diferente da sua, julgava-a 'demoníaca' já que nào era cristã. $O$ dualismo social se prolongou por conseguinte - justificando-se também - pela oposiçào entre as forças do Bem, que iam de Deus ao senhor de engenho, e as forças do Mal, que iam de Satã até os seus sequazes das senzalas e dos mocambos. Assim, ele recuperou a 'boa consciência' e as danças místicas dos negros, ao redor de suas pedras lavadas de sangue de animais sacrificados, tornavam válida, aos seus olhos, a distância social que mantinha entre si e eles. A definição de civilizações africanas como diabólicas foi uma racionalização da brutalidade e da falta de humanidade da escravidão./ $\mathrm{O}$ folclore, que mantém as crenças dos séculos anteriores, conserva sempre traços desta falsificação, mais ou menos consciente, das religiōes do negro, desta ligaçào entre o paganismo do escravo e a dualidade da estrutura social. As crenças e os ritos religiosos dos negros sào considerados como sendo o lado demoníaco, a margem obscura, desse dualismo essencial:

O Negro não adora Deus;

É Calunga que ele ama.

Todo Branco quer se tornar rico;

Todo mulato é um pretensioso,

Todo cigano é um ladrão

E todo negro um feiticeiro.

O mulato jamais deixa sua faca

Nem o branco sua sabedoria,

O 'cabra' não deixa nunca sua aguardente,

Nem o negro seu fetichismo. 
Quando negro velho morre

Exala um odor tão forte

Que Nossa Senhora nào o aceita

E o negro nào entra no céu.

O negro tem pé de animal, unhas de caça e calcanhar rachado, seu dedinho é como o pepino de Sào Paulo, o que é, mais ou menos, a representaçào tradicional que o cristào da Idade Média fazia do Diabo". As Religiões Africanas no Brasil, $1^{\circ}$ vol., São Paulo, Livraria Pioneira, 1971, pp. 198-199

10 Luís da Câmara Cascudo. Meleagro, Rio de Janeiro, Agir, 1951, pp. 11-13, (grifo meu).

11 "Não existe, por assim dizer, sistema religioso, antigo ou recente, no qual, sob formas diversas, não se encontrem lado a lado como que duas religiōes, as quais, embora estreitamente unidas e até penetrando-se mutuamente, não deixam de ser distintas. Uma dirige-se às coisas da natureza, seja às grandes forças cósmicas, como os ventos, os rios, os astros, o céu, etc., seja aos objetos de todo tipo que povoam a superficie da terra, plantas, animais, pedras, etc.; por esse motivo lhe dão o nome de naturismo. A outra tem por objeto os seres espirituais, os espiritos, almas, gênios, demônios, divindades propriamente ditas, agentes animados e conscientes como o homem, mas que se distinguem dele pela natureza dos poderes que lhes são atribuidos e, sobretudo, pela característica particular de nào afetarem os sentidos do mesmo modo: normalmente nào sào perceptíveis a olhos humanos. Chama-se animismo essa religião dos espíritos". Émile Durkheim. As Formas Elementares da Vida Religiosa, São Paulo, Martins Fontes, 1996, pp. 34

12 O nome Aurísio, talvez se deva ao fato do templo de Saturno localizar-se no sopé da colina Capitolina, onde ficava o aerarium, o tesouro público do povo romano, o que deu margem à expressão aerarium Saturni. Paul Harvey, Dicionário Oxford de Literatura Clássica, p. 455. Cf. tb. Jean Chevalier e Alain Gheerbrant, Dicionário de Símbolos, Rio de Janeiro, José Olympio, 1988, p. 443

13 Sérgio Buarque de Holanda, num capítulo sugestivo, chamado "Botica da Natureza", afirma ser um costume tanto indígena quanto do colono português, 
e depois mameluco, a busca de fórmulas salvadoras, colocando a religião para servir a fins terrenos e demasiadamente humanos. Entre elas, ele cita a "oração de Sào Marcos", que chegou a alcançar celebridade em algumas regiōes de São Paulo. Ele diz: "Vinda do reino, a crença no poder mágico da palavra falada ou escrita encontrou, entre nós, condições adequadas para ganhar terreno. É de notar que os próprios índios já se serviam a seu modo de fórmulas de encantamento, invocações ou rezas, em que certas combinações de palavras, pronunciadas de certa maneira e repetidas determinado número de vezes, podem livrar de qualquer perigo a quem as recite devotamente. Algumas vezes chega a surpreender, nas que Koch-Grünberg coligiu em suas expedições ao extremo norte da Amazônia, a similitude que apresentam com as orações e ensalmos caboclos.[...]/ Na forma, no conteúdo, na intenção, tais os pontos de contato existentes entre essa e certas oraçòes mágicas largamente conhecidas dos sertanejos, como a de São Marcos, ou a de Santa Clara [...] que é lícito perguntar se não haveria aqui, mais do que mera coincidência, o resultado de uma interação assídua de crendices importadas e práticas indígenas". Caminhos e Fronteiras, Rio de Janeiro, José Olympio, 1957, pp. 102-104

14 Como as referências "direita" e "esquerda" aparecem mais de uma vez na história, vale a pena fornecer, em apoio a possíveis interpretações, dois dados. Um, é amplo e histórico, que é lembrar como, depois de 30, tornaram-se acirrados os debates e as polarizações entre esquerda e direita na política brasileira, nos quais se envolveram a fundo os escritores, poetas e romancistas, e divergiram sobre o engajamento ou nào das suas obras. E o outro é mais restrito, faz parte da prática do catimbó, que distingue como direita e esquerda os trabalhos para o bem e para o mal: "O trabalho do 'mestre' não se chama feitiço nem muamba, coisa-feita ou cangerê. O mestre quem entende de Catimbó diz sempre 'fumaça'. O trabalho para o Bem, tratamento médico, remédios e conselhos, orientaçòes benéficas, dádivas de amuletos, é a fumaça às direitas. Trabalho para o Mal, vinganças, dificultar negócios, obstar casamento, enfermar alguém, conquista de mulher casada, despertar paixão sem ser para bom fim, é a fumaça às 
esquerdas". Luís da Câmara Cascudo, op. cit., p. 33 (os grifos sào do próprio autor).

15 Guimaràes, nesta passagem, aproveita-se para fazer uma densa reflexão sobre a palavra, talvez a mais significativa da sua obra sobre o tema. Mas, ao contrário do que viu a maior parte dos críticos que a analisou, o seu tema principal não é tanto o da beleza da palavra como o do seu poder. Elas podem ser como os pássaros, ter canto e plumagem, mas sâo mediadores entre o céu e a terra distintos deles, pois cumprem a função inversa. Se na beleza dos cantos e da plumagem dos pássaros podemos contemplar a obra da criaçào, "Deus pintou o surucuá [...]/ Surucuá fugiu pra cá”, as palavras fazem o caminho inverso, elas levam ao divino os nossos apelos, que devem também ser belos, tanto quanto o possam a criação humana, imitando a beleza da criação; talvez seja essa a maior funçào da poesia para Guimaràes, o de religar o homem ao divino, graças ao poder dado pela beleza, seja de encantamento como de invocação. De outro modo, essa reflexão parece nos dizer: o poder da palavra de chegar até o divino, eqüivale à beleza dos pássaros que o revela a nós. Esse poder da palavra se manifesta, principalmente, através da reza, não sendo por acaso que uma, a de São Marcos, dá o título à novela. Oswaldino Marques foi o primeiro que se deteve, num ensaio pioneiro, na análise dessa passagem, porém ressaltou nela só as novas funções poéticas e estilísticas que a palavra adquiria na literatura do autor: " $A ́$ falta de um termo corrente, fomos forçados a cunhar o vocábulo prosopoema, para nomeá-la". Ele deixa de apreciar o seu poder e a sua função também religiosa, de religare, que é de fato o que o autor está procurando ressaltar. Cf. "Canto e plumagem da palavra", in A Seta e o Alvo, Rio de Janeiro, MEC/INL, 1957, p. 21

16 Rodolpho von Ihering. Dicionário dos Animais do Brasil, p. 742

17 "O nome Serpente Emplumada (Quetzalioatl para os antigos mexicanos, Kukulian para os maias, Guiumatz para os quichés) é simplesmente a leitura fonética do hieróglifo que designa nas esculturas centro-americanas um personagem histórico, rei-sacerdote dos toltecas, posteriormente elevado à categoria de divindade. Na qualidade de deus, ele é protagonista de mitos que relatam a 
restauração dos humanos na Terra durante o Quinto Sol, depois da destruição do Sol (ou era) anterior, graças à invenção do milho com o qual se faz a carne dos homens". Pierre Brunel, Dicionário de Mitos Literários, p. 834.

18 A recusa da busca da perfeição não era só um fato caprichoso da poética modernista, tendo em vista chocar a estética classicizante da poesia da época. Ela se fazia necessária como forma de poder apreciar as manifestaçòes da arte popular, onde a mistura do alto e do baixo, do popular e do culto substituíam o gosto de pureza da arte clássica. Isto pode ser visto nesta crônica de Mário de Andrade, onde ele relata um ensaio de uma "Chegança pra Natal", que foi assistir na cidade de Natal: " $E$ fico maravilhado. Está claro que não se trata duma obra-de-arte perfeita como técnica, porém desde muito já que percebi o ridículo e a vacuidade da perfeição. Postas em foco inda mais, pela monotonia e vulgaridade do conjunto, surgem coisas dum valor sublime que me comovem até à exaltação./ Todas essas danças-dramáticas inda permanecidas tào vivas na parte norte e nordeste do país, andam muito misturadas, umas trazem elementos de outras, influências novas penentram nelas; junto duma liçào camoniana brota um brasileirismo danado [...]". O Turista Aprendiz, p. 236. Por outro lado, não era raro Mário e outros modernistas assumirem uma atitude provocativa de pândega sobre vários assuntos sérios ou elevados, como o próprio Mário confessa nas suas carta a Bandeira: “Não acho que o 'em-vez-não' italiano fique na nossa língua. Empreguei-o por pândega. Mas porém nos meus artigos propositalmente escritos em brasileiro você não o encontrará vez só. Antes o empregava. Por pândega já disse"; "Sou um fenômeno culto, sei disso e não me afasto disso. Agora: numas cartas escritas alegremente pra amigos, por brincadeira, com intenção evidentemente pitoresca uso exageros de pândega, pra rir”. Correspondência Mário de Andrade \& Manuel Bandeira, org. de Marcos Antonio de Moraes, São Paulo, EDUSP/IEB, 2000, respect. pp. 171 e 182

19 Entre outras características do deus, uma deve ser ressaltada, pois o faz responsável pela possessão que acomete o narrador-protagonista e esclarece a entidade que o ameaça e tenta perdê-lo: "Atribuia-se a Pan a fama de causar terrores súbitos e infundados, especialmente os sentidos por viajantes em luga- 
res ermos e remotos, conhecidos conseqüentemente como terrores pânicos". Paul Harvey, Dicionário Oxford de Literatura Clássica, p. 377 Um fato natural, o pânico do isolamento na mata, era explicado pelos antigos como uma possessão do deus.

20 Sagarana, $14^{a}$ ed., Rio de Janeiro, José Olympio, 1971, pp. 242

21 Câmara Cascudo refere-se a Pà como entidade demoníaca associada ao bode nos ritos de feitiçaria: "Os animais mais populares nos candomblés e macumbas são os mais velhos na feitiçaria de Europa velha. O Bode, Pã, Azazel, bode expiatório dos judeus, representante típico do Diabo, das forças do Mal, presidindo o Sabat, acompanhando Baco Sabasius, bode preto, bode sujo, na sinonímia popular do Demônio, Bafomet, o ídolo da cabeça de bode, também era num bode que a feiticeira voava para as reuniões, quando dispensava voar montada num cabo de vassoura". Op. cit., pp. 182-183.

22 Aqui, nesta primeira formulaçào da sua teoria amorosa, não é possível reconhecer as fontes platônicas, neo-platônicas, herméticas e místicas a que se refere Benedito Nunes, no seu ensaio "O amor na obra de Guimaràes Rosa". As suas fontes parecem ser outras, algumas, mais arcaicas e tradicionais da cultura grega, outras, aristotélicas, e, apesar das variaçòes, continuarão as mesmas até o Grande Sertão: Veredas.

23 Isto parece que foi percebido e representado por Santa Rosa, na capa que fez para a $3^{a}$ edição do Sagarana, que, infelizmente, foi abandonada nas ediçôes posteriores.

24 A oposição Sol-Lua, como uno e múltiplo, "induz, com efeito e de forma explícita, uma extrema valorização da função do olhar, a visão sensível, a dos olhos, identificada com a visão intelectiva, a que permite, graças à espiritualidade da luz, distinguir não somente o belo do feio mas também o bem do mal. Esta supremacia do olho sobre os outros sentidos será abundantemente desenvolvida, nas suas variações poéticas e metafóricas, ao longo dos séculos XVI e XVII. Até nas descrições anatômicas dos poetas barrocos, o olho aparece como intermediário entre o mundo sensível e o mundo inteligível, duplo do Sol, cuja 
luz ilumina os espíritos e também a matéria”. Pierre Brunel, Dicionário de Mitos Literários, p. 68

25 Oswald de Andrade, Poesias Reunidas, Rio de Janeiro, Civilização Brasileira, 1974, p. 164

26 Mário de Andrade, Macunaíma, Edição crítica Telê Porto Ancona Lopez, Coleçào Arquivos, p. 114

27 Luís da Câmara Cascudo. Dicionário do Folclore Brasileiro, Belo Horizonte, ITATIAIA, 1984, p. 475

28 Mestre Carlos é uma referência significativa na obra de Mário de Andrade. No O Turista Aprendiz, ele contou deste modo a sua história: "Aqui no Rio Grande do Norte os catimbozeiros não falam nem em santos nem em deuses. Os espíritos invocados são 'mestres', como mestres são também os chefes de catimbó, os 'pais de terreiro' da Bahia.[...] A história de Mestre Carlos é bonita. Desde muito cedo se mostrou um piá excepcional. Travesso como o Cão, andava no meio de mulheres-perdidas e de mais gente muito livre. $\mathrm{O}$ pai dele, Inácio de Oliveira, era catimbozeiro, tinha desgosto do filho e nào o queria iniciar na feitiçaria./ Porém Carlos 'aprendeu sem se ensinar'. Um dia que o pai saiu de casa, Carlos com 12 anos apenas, penetrou no 'Estado' (sala onde se realizam as sessões), tirou os objetos imprescindíveis de invocação e saiu com eles. Foi num mato de juremeiras e iluminado por uma presciência maravilhosa, conseguiu abrir uma sessão sozinho e invocar um mestre. Logo 'caiu no santo', quem sabe o que fez com o santo no corpo e no fim, como em geral sucede, quando o mestre invocado se 'desmaterializou' outra vez, caiu desacordado./ O pai chegou em casa, Carlinhos nada de voltar. No dia seguinte a inquietação principiou. Andaram campeando o menino por toda a parte e no outro dia seguinte, Inácio de Oliveira desesperado, reuniu gente e fez uma sessão. Quando caiu em transe, que Mestre entrara no corpo dele? Nada menos que mestre Carlos, o mestre menino, tirando um canto novo, cuja melodia já possuo [...]", São Paulo, Livraria Duas Cidades, 1976, pp. 249. Sobre a importância e o valor positivo que tem a figura de Mestre Carlos na constituição do imaginário da obra de Mário, como um de seus "grandes sinais", v. Victor Knoll, Paciente 
Arlequinada, p. 33 e pp. 176. Tanto Victor Knoll (v. o cap. Posição) como Gilda de Mello e Souza observam como a poesia de Mário, e de modo especial esse poema, tem como um dos seus principais elementos constitutivos o enigma, exigindo do leitor, principalmente, um esforço intelectual de decifração: “por um paradoxo curioso, é este 'Brazào', rigorosamente cifrado, que nos fornece o melhor exemplo para deslindar o rigoroso código poético de Mário de Andrade", in Apresentação, Mário de Andrade: melhores poemas, p. 13. 29 Mário de Andrade. Poesias Completas, Belo Horizonte, ITATLAIA/EDUSP, 1987, p. 320. Citando os catimbozeiros, Câmara Cascudo fala também de João Germano das Neves, “que 'fechou o corpo' de Mário de Andrade em Natal”. Op. cit., p. 43.

30 Para Victor Knoll, é deste modo que Mário vê o catimbó e Mestre Carlos: “Além de ter a sua proveniência na região amazônica, o catimbó é ainda julgado como um produto nacional de religiosidade - expressão de uma religião própria da terra ou onde os valores da terra predominam. $\mathrm{Na}$ vegetação virgem do Amazonas não há metáforas européias. Ora, sendo o catimbó uma criação amazônica e exprimindo uma religiosidade nacional, percebemos o alcance que adquire o estabelecimento de um vínculo entre Mestre Carlos e o sinal que o poeta indaga da ponte das Bandeiras"; “ Jurema, Amazonas e infância sào as significações externas de Mestre Carlos enquanto que sinceridade, descobridor de segredos, protetor da juventude, noticioso e propiciador do amor são as suas significações internas. A combinaçào e a totalidade destas significações apresentam Mestre Carlos como sinal do poeta". Victo Knoll, op. cit., pp. 189 e 193 31 O poema foi escrito em "10-XII-37", assim está datado no manuscrito, e não consegui até agora informações se foi publicado na imprensa ou em alguma revista antes de 1941, quando foi reunido no livro $A$ Costela do Grã Cão, no volume Poesias. A novela foi escrita em 37 e "a 31 de dezembro de 1937, entreguei o original, às 5 e meia da tarde, na Livraria José Olympio", escreve Guimarães Rosa como depoimento a João Condé. $\mathrm{Na}$ mesma carta, ele faz esta confissão muito sugestiva sobre a novela: "Demorada para escrever, pois exigia grandes esforços de memória, para a reconstituição de paisagens já muito afunda- 
das. Foi a peça mais trabalhada do livro". Vilma Guimarães Rosa, Op. cit., pp. 334-335. O Estado Novo tinha sido decretado por Getúlio um pouco antes, em 10 de novembro, e Jôao Luiz Lafetá fez uma aproximaçào muito pertinente entre os sinais do tempo histórico - quando em nome de uma unidade nacional e centralização do poder se queimavam em praça pública os símbolos estaduais, como os hinos, brasões e bandeiras - e os do poema de Mário, contrastando-os com o estado de espírito efusivo e otimista do Noturno de Belo Horizonte, quando o autor ainda dizia sobre a união dos 22 estados brasileiros: "Nós somos na terra o grande milagre do amor!", e as nossas particularidades permitiam: “A fremente celebração do Universal!". O crítico, finamente arguto e desconfiado como sempre foi, preferiu historicizar ao invés de entrar em aras metafísicas, procurando alguma pista para entender um fim de ano com tanta inspiraçào, espíritos soltos, possessões e apelos a santo salvador e catimbozeiros. Figuração da Intimidade, São Paulo, Martins Fontes, 1986, pp. 150.

32 Gilda de Mello e Souza faz uma leitura muito precisa da representaçào do boi nas duas obras citadas do Mário e que nos ajuda muito a compreender também a intensificação de sentido que Guimarães Rosa deu a ele: "Mas o boi não é apenas o animal heráldico do Brasil, como o leão é britânico e a águia bicéfala é austríaca; representa, ainda, como metáfora, um dos 'grandes sinais' do escritor, a marca de sua personalidade construída, de seu ethos. Sob a dupla feição de símbolo do Brasil e sinal do poeta, a imagem ocorre várias vezes em sua poesia, inclusive em 'Brazâo', um de seus poemas mais cifrados. Nada de estranho, por conseguinte que, em Macunaima, Mário de Andrade tivesse procedido a uma identificação semelhante, desta vez entre o animal simbólico do Brasil e Macunaíma, o herói simbólico da nacionalidade. É nesse sentido que devemos interpretar a intercalação, no final do livro, de um dos trechos mais importantes do Bumba-meu-Boi. Na esteira do Golden Bough, de Frazer, Mário de Andrade interpreta o núcleo central do bailado - a morte e ressureição do boi - como um traço de culto da primavera, isto é, como a destruição e o ressurgimento do principio vital. Assim, ao interromper a narrativa para descrever minuciosamente o episódio culminante da dança dramática, estava usando-o como metá- 
fora, como um grande sinal premonitório do desenlace dramático que se preparava. A morte e a ressureiçào do boi era como que a antecipaçào do sacrifício do herói, que logo mais seria destroçado neste mundo, para em seguida ressurgir no céu em forma de estrela". O Tupi e o Alaúde, São Paulo, Duas Cidades, 1979, pp. 18-19.

33 Este estudo, que é apenas parte de um dos capítulos de um trabalho maior sobre Rosa, foi apresentado pela primeira vez no curso de pós-graduação "Literatura e crítica no Brasil: autores principais", coordenado por mim e pelos profs. José Miguel Soares Wisnik e Alcides Celso de Oliveira Villaça, na USP, no dia 12 de novembro de 1999. 